\title{
Strategi Diplomasi Indonesia dalam Pembebasan Papua Tahun 1949-1963
}

\author{
Berlian Susetyo, Ravico \\ Museum Subkoss Garuda Sriwijaya \\ Institut Agama Islam Negeri (IAIN) Kerinci \\ berlian.susetyo.nvb@gmail.com
}

\begin{abstract}
The period of Indonesia's independence struggle in the effort to liberate West Irian became a big agenda in the eradication of colonialism. So that diplomatic efforts are carried out both open and closed diplomacy. To answer this problem historical research is carried out using the steps of the research method namely heuristics, verification, interpretation and historiography. The results of the research included open diplomacy through the general assembly of the United Nations in 1954-1957, the 1955 Asian-African Conference and the policy of confrontation. Furthermore, Closed Diplomacy through US diplomat Ellsworth Bunker, who was directly governed by the UN Secretary General U Thant, this proposal became a way out towards peace to stop the dispute between Indonesia and the Netherlands over the West Irian problem.
\end{abstract}

Keywords: Diplomacy, Open Diplomacy, Closed Diplomacy

Abstrak. Masa perjuangan kemerdekaan Indonesia dalam upaya pembebasan Papua menjadi agenda besar dalam penghapusan kolonialisme. Sehingga upaya diplomatik dilakukan baik itu diplomasi terbuka maupun tertutup. Untuk menjawab permasalahan tersebut dilakukan penelitian sejarah dengan menggunakan langkahlangkah metode penelitian yaitu heuristik, verifikasi, interpretasi dan historiografi. Hasil penelitian meliputi diplomasi terbuka dengan cara melalui sidang umum PBB tahun 1954-1957, Konferensi Asia-Afrika 1955 dan kebijakan kofrontasi. Selanjutnya Diplomasi Tertutup melalui diplomat Amerika Serikat Ellsworth Bunker yang diperintah langsung oleh Sekjen PBB U Thant, usulan ini menjadi jalan keluar menuju perdamaian untuk menghentikan perselisihan antara Indonesia dan Belanda atas masalah Papua.

Kata Kunci: Diplomasi, Diplomasi Tertbuka, Diplomasi Tertutup

\section{PENDAHULUAN}

Dalam sejarahnya, pulau Papua memiliki berbagai nama seperti Nova Guinea yang diberikan oleh bangsa Spanyol. Hal ini sesuai pendapat Usman (2010, h. 9) bahwa:

Istilah Papua disematkan oleh gubernur pertama Portugis, Jorge de Meneses tahun 1528 M. Ketika de Meneses mengunjungi Pulau Waigeo dan bertemu dengan penduduk asli yang berkulit hitam dan berambut keriting, kemudian ia menyebut penduduk tersebut dengan 
orang Papua. Namun, pelaut asal Spanyol bernama Inigo Ortiz de Retes menamai dengan sebutan Nova Guinea (Guinea Baru) kepada pulau Irian, sebab pantainya memperlihatkan persamaan dengan pantai Guinea yang ada di wilayah Afrika.

Penemuan pulau Papua tidak terlepas dari bangsa Eropa yang melakukan penjelajahan samudera untuk mencari rempah-rempah, salah satunya Belanda. Hal ini disebabkan oleh diblokadenya pelabuhan perdagangan Konstatinopel oleh Turki Utsmani pada tahun 1453 M, peristiwa ini menyebabkan pedagang Eropa mencari sendiri daerah yang menjadi pusat penghasil rempah-rempah di dunia Timur. Sehingga Belanda melakukan ekspedisi ke wilayah Irian dengan tujuan untuk mencari rempahrempah dan potensi alam lainnya (Djaja, 2015, h. 134).

Menurut Usman (2020), "Pelaut-pelaut Belanda berlayar ke Irian antara tahun 1600-1700 M. Banyak sekali pelayaran dilakukan pelaut Belanda ke pulau tersebut dengan misi mencari emas dan kulit pohon Massci yang diperlukan untuk wewangian, tak terkecuali ekspedisi dari Jan Carstenzs." Penjelajahan Carstenzs di pulau ini untuk mencari hasil bumi dalam kepentingan perdagangan kala VOC didirikan tahun 1602 M. Dan tahun $1623 \mathrm{M}$, ia berhasil menemukan puncak salju yang diberi nama sama dengan dirinya. Puncak salju tersebut dinamakan puncak Cartensz yang saat ini disebut pegunungan Jayawijaya (h. 10).

Pelayaran yang dilakukan oleh bangsa Belanda tersebut, maka Papua menjadi wilayah jajahan Belanda atas kekayaan alam yang dimilikinya. Tahun 1828, untuk menampakkan kekuasaannya atas Papua, Belanda mulai mendirikan benteng Du Bus di Teluk Triton sebagai tempat pemukiman hingga berlanjut pada masa kolonialisasi.

Tahun 1898, Parlemen Belanda menyepakati berdirinya pemerintahan kolonial di Papua. Kemudian Papua dibagi menjadi dua afdeeling yaitu Afdeeling Nieuw Guinea Utara dan Afdeeling Nieun Guinea Barat-Selatan. Pembangunan kedua wilayah tersebut merupakan awal pemekaran wilayah yang 
dimaksudkan untuk mengendalikan pemerintahan atas kehadiran kolonial Belanda di tanah Papua. Sehingga eksploitasi kekayaan alam akan lebih mudah dilaksanakan.

Walaupun proklamasi telah digaungkan tahun 1945, banyak wilayah di Indonesia belum merdeka seutuhnya. Gejolak perjuangan melawan kolonialisme terus digemakan baik dengan diplomasi ataupun genjatan senjata. Papua menjadi daerah perdebatan antara pihak Indonesia dan Belanda, turut menjadi penghambat Indonesia untuk menyusun sistem pemerintahan yang baik. Daerah yang masih menyisakan perdebatan itu ialah Karesidenan Nieuw Guinea (Papua). Perdebatan ini disebabkan karena daerah yang didominasi oleh penduduk berkulit hitam ini, memiliki sejuta pesona alam dan kekayaan alam berupa bahan tambang yang luar biasa. Sehingga membuat Belanda ingin menguasai daerah tersebut dalam jangka waktu yang lama.

Dalam sudut pandang Indonesia, wilayah Papua sebagai perjuangan kemerdekaan dan masuk ke wilayah Negara Kesatuan Republik Indonesia, serta upaya pembebasan tanah air dan bangsa dari segala bentuk penjajahan. Hal itu berdasarkan pada pembukaan UUD 1945. Sehingga perjuangan tersebut menempatkan kedua negara yaitu Indonesia dan Belanda bertemu untuk menyelesaikan permasalahan, salah satunya masalah status Papua. Akhirnya, Konferensi Meja Bundar diambil sebagai langkah penyelesaian masalah kedua negara.

Pemerintah Indonesia telah melakukan kebijakan diplomasi dalam upaya membebaskan Papua, tetapi upaya diplomasi yang dilakukan mengalami kegagalan. Ketika usaha-usaha di bidang diplomasi masih saja tidak membawakan penyelesaian, hal ini membuat pemerintah Indonesia mulai mengambil sikap keras terhadap Belanda. Pembatalan Uni IndonesiaBelanda tahun 1954, kemudian diikuti dengan pembatalan secara sepihak perjanjian Konferensi Meja Bundar (KMB) oleh Indonesia tahun 1956 
menjadi pertanda keretakan hubungan antara Indonesia dan Belanda (Usman, 2010, h. 83).

Ketegangan antara Indonesia dan Belanda semakin memuncak, terlebih setelah pemerintah Belanda mengajukan gagasan untuk melakukan dekolonisasi dan internasionalisasi Papua di forum PBB. Pihak Belanda berusaha melegalisasi Rencana Undang-Undang Dewan Papua lengkap dengan bendera dan lagu kebangsaannya. Langkah ini tentu saja akan menjurus pada pembentukan negara Papua yang sangat bertentangan dengan piagam kedaulatan RI (Setyawan 2011, h. 103-104).

Perjuangan pembebasan Papua mencapai puncaknya pada tahun 1962. Meskipun sebelumnya usaha-usaha di bidang diplomasi selalu mengalami kegagalan, kemudian dilakukan pula konfrontasi militer yang dilancarkan oleh Komando Mandala. Hal ini berhasil memaksa Belanda untuk bersedia membuka kembali diplomasi dengan pemerintah Indonesia dalam menyelesaikan kasus Papua melalui UNTEA (United Nation Temporary Executive Authority) sebagai perwakilan Perserikatan Bangsa-Bangsa. Dengan persetujuan New York yang ditandatangani kedua negara tanggal 15 Agustus 1962 (Usman, 2010, h. 91). Secara resmi kedaulatan Papua diserahkan kepada Indonesia pada tanggal 01 Mei 1963. Hal ini adalah puncak perjuangan bangsa Indonesia, dan dunia pun mengakui bahwa Papua adalah bagian dari wilayah Indonesia.

Berdasarkan uraian di atas, penulis tertarik untuk mengkaji lebih dalam upaya diplomasi yang dilakukan pemerintah Indonesia untuk membebaskan Papua dari kolonial Belanda. Hal ini dianggap penting mengenai perjalanan sejarah bangsa dalam mempertahankan NKRI dari belenggu kolonialisme.

Untuk menjawab permasalah di atas maka digunakan metode penelitian sejarah (bistoris). Menurut Abdurahman (2007), penelitian sejarah adalah "Penelitian yang mendeskripsikan dan menganalisis peristiwa-peristiwa 
masa lampau" (h. 63). Sementara menurut Gottschalk (19859, penelitian sejarah merupakan "Proses menguji dan menganalisis secara kritis rekaman dan peninggalan masa lampau" (h. 39).

Tahapan penelitian yang digunakan sebagaimana diungkapkan oleh Bernhein (dalam Irwanto, 2012, h. 11), ialah Heuristik (Menemukan sumber), Verifikasi (kritik sumber), Interpretasi (Kredibilitas sumber), dan Historiografi (Penyajian tulisan atau Darstellung).

Heuristik merupakan tahap pertama dalam penelitian historis setelah penentuan topik bahasan yaitu mengumpulkan sumber-sumber. Sumbersumber yang digunakan dalam penelitian ini diantaranya buku dan jurnaljurnal ilmiah. Dijelaskan oleh Rochmat (2009), bahwa kemampuan dan menghimpun sumber-sumber yang diperlukan dalam penulisan sejarah dikenal dengan tahapan heuristik (h. 147).

Tahap berikutnya ialah verifikasi atau kritik sumber. Kritik sumber bertujuan untuk memperoleh keabsahan sumber (Abdurahman, 2007, h. 68). Kritik sumber ialah kritik peneliti terhadap sumber sejarah yang diperolehnya. Apabila peneliti telah yakin bahwa sumber sejarah yang telah diperoleh benar-benar asli. Akan tetapitetap harus dilakukan kritik sumber terhadapnya dari segi-segi yang lain (Irwanto, 2012, h. 77-78). Untuk itu, maka diperlukan kritik sumber yang terbagi menjadi dua bagian antara lain kritik ekstern dan kritik intern.

Sumber-sumber yang telah diverifikasi baik kritik ekstern maupun kritik intern, kemudian dilakukan interpretasi yaitu sebuah penafsiran dari sumber tersebut. Setelah fakta telah diuji kebenarannya, kemudian ditafsirkan. Fakta yang bermakna karena saling berhubungan atau saling menunjang (Rochmat, 2009, h. 150) kemudian disusun dengan baik.

Tahap akhir dalam metode penelitian historis yaitu historiografi, yaitu langkah penulisan, pemaparan atau pelaporan hasil penelitian sejarah yang telah dilakukan. Dengan kata lain, penulisan sejarah yang didasarkan pada 
analisis fakta-fakta, disusun menjadi kisah baru dengan kecenderungan seorang peneliti (Abdurahman, 2011, h. 117).

\section{HASIL DAN PEMBAHASAN}

\section{Hasil Temuan}

Diplomasi merupakan seni memperjuangkan kepentingan negara melalui tindakan perundingan damai merupakan tujuan diplomasi yang sebenarnya. Apabila upaya diplomasi tersebut tidak menjadi solusi penyelesaian, maka penggunaan kekuatan nasional dapat dilakukan untuk mencapai tujuan. Untuk mencapai tujuan tersebut, dilakukan dengan jalan pengerahan kekuatan nasionalsebagai kekuatan ancaman (Roy, 1995, h. 5).

Langkah Indonesia dalam perjuangan membebaskan wilayah Papua dari belenggu kolonial Belanda ialah menggunakan jalur diplomasi, yaitu melalui Perserikatan Bangsa-Bangsa. Diplomasi ini digunakan sebagai langkah penyelesaian dari segala bentuk permasalahan dengan cara damai. Oleh karena itu, strategi diplomasi digunakan Indonesia dalam membebaskan wilayah Papua adalah strategi diplomasi terbuka dan strategi diplomasi tertutup.

\section{Diplomasi Terbuka}

Diplomasi terbuka dicapai harus dengan cara terbuka dan diketahui umum. Diplomasi ini mengandung tiga gagasan yaitu: 1). Harus tidak ada perjanjian rahasia, 2). Negosiasi harus dilakukan secara terbuka, 3). Apabila suatu perjanjian sudah dicapai, tak boleh ada usaha dibelakang layar untuk mengubah ketetapannya secara rahasia (Roy, 1995, h. 79).

\section{Sidang Majelis Umum Perserikatan Bangsa-Bangsa (1954-1957)}

Peran PBB dalam perjuangan Indonesia merebut Papua sebagai bagian integral wilayah kesatuan RI telah tampak ketika Wakil Tetap RI di PBB yaitu Sudjarwo Tjondronegoro, mengajukan permintaan kepada Sekjen PBB agar masalah Papua dapat dimasukkan dalam agenda Sidang Majelis Umum PBB (Wisnumurti, 1998, h. 78). 
Usaha pemerintah Indonesia untuk membawa persoalan Papua ke forum PBB mendapat reaksi keras dan penolakan dari kolonial Belanda. Belanda beranggapan bahwa PBB tidak berhak ikut campur dalam persoalan Papua, dan menilai Indonesia melakukan ekspansi karena menyalahtafsirkan hasil Konferensi Meja Bundar yaitu permasalahan Papua diselesaikan melalui pertemuan kedua negara saja. Walaupun begitu, Indonesia berhasil membawa masalah Papua di forum internasional tersebut melalui Sidang Majelis Umum PBB dari tahun 1954 sampai tahun 1957 (Karseno, 2011, h. 62). Dalam Sidang Majelis Umum PBB ke-9 tahun 1954, rancangan resolusi Papua atas prakarsa Indonesia tidak memperoleh dukungan yang diperlukan. Begitu pula dalam sidang PBB ke-10 tahun 1955 sampai sidang PBB ke-12 tahun 1957 (Cholil, 1979, h. 12).

Kegagalan ini tidak lepas dari jumlah keanggotaan PBB yang lebih menguntungkan Belanda. Pada waktu itu, jumlah anggota Majelis Umum PBB sebagian besar masih didominasi oleh negara-negara Barat, sedangkan mayoritas negara-negara berkembang pada saat yang sama masih menjadi koloni negara Barat dan belum merdeka (Wisnumurti, 1998, h. 78-79).

Atas kegagalan di forum PBB tersebut, maka strategi Indonesia dalam pembebasan Papua berubah dari diplomasi secara damai menjadi diplomasi tekanan dengan melakukan konfrontasi di segala bidang, termasuk pengerahan kekuatan militer sebagai kekuatan ancaman.

\section{Konferensi Asia Afrika (1955)}

Usaha Indonesia dalam memperoleh dukungan internasional dalam memperjuangkan pembebasan Papua, ditempuh melalui jalan lain yakni lewat forum Konferensi Asia Afrika (KAA) dilaksanakan di Bandung tahun 1955. Pemerintah Indonesia menjadikan permasalahan Papua sebagai perjuangan dari sisa-sisa kolonialisme dan imperialisme dunia.

Konferensi Asia Afrika mendukung secara penuh kedudukan Indonesia dalam persoalan pembebasan Papua yang didasarkan atas 
persetujuan yang telah dicapai antara Indonesia dan Belanda sebelumnya. Selain itu, konferensi ini juga mendesak pemerintah Belanda untuk secepat mungkin memulai lagi perundingan-perundingan, untuk menepati kewajibankewajiban sebagaimana ditentukan dalam persetujuan KMB. Kemudian pula dinyatakan harapan agar PBB mau membantu pihak-pihak yang bersengketa untuk mencapai penyelesaian perselisihan antara Belanda dan Indonesia dengan jalan damai (Cholil, 1979, h. 14).

Akan tetapi, bentuk sokongan dari negara-negara peserta Konferensi Asia Afrika (KAA) ini tetap tidak membawakan hasil yang signifikan pada Sidang Majelis Umum PBB ke-X tahun 1955 dan Sidang Majelis Umum PBB ke-XI tahun 1956, hal ini dikarenakan jumlah negara keanggotaan PBB masih didominasi negara-negara Barat, sedangkan negara-negara Asia Afrika sendiri masih menjadi koloni negara-negara Barat.

Atas sikap dan solidaritas diantara negara-negara Asia Afrika turut menjadi pemicu semangat dalam penghapusan kolonialisme yang ada di dunia, termasuk dalam rangka mengusir Belanda yang masih membelenggu Papua. Sehingga hal ini mendasari terselenggaranya Konferensi Asia Afrika. Harapan dari konferensi ini turut menjadi resolusi dukungan dalam perundingan pada forum sidang umum PBB, namun ternyata kembali gagal. Akibat komposisi anggota PBB masih didominasi negara-negara Barat, sedangkan negara-negara Asia Afrika masih menjadi daerah kolonialisme Barat. Hal ini tentu membuat Indonesia terus berupaya dengan menempuh jalan lain untuk menyelesaikan sengketa Papua, tak terkecuali melalui kekuatan nasionalnya.

\section{Strategi Indonesia Pasca Kegagalan Diplomasi dalam Membebaskan}

\section{Papua}

Kegagalan usaha penyelesaian secara damai atas sengketa Papua melalui perundingan-perundingan damai, baik itu melalui Perserikatan Bangsa-Bangsa ataupun dukungan dari Konferensi Asia Afrika, telah 
menyebabkan perubahan sikap perjuangan Indonesia yaitu dari defensif ke ofensif; dari meminta Belanda untuk berunding, menjadi memaksa Belanda untuk berunding. Hal ini membuat Indonesia kemudian menjalankan kebijakan konfrontasi total terhadap Belanda (Karseno, 2011, h. 62). Hal ini sesuai konsep diplomasi yang dijelaskan oleh Roy (1995) bahwa:

"Apabila upaya diplomasi tidak menjadi solusi penyelesaian, maka penggunaan kekuatan nasional dapat dilakukan untuk mencapai tujuan. Dalam mencapai tujuan tersebut, dilakukan dengan mengerahkan kekuatan nasional sebagai kekuatan ancaman (h. 5).”

Kebijakan konfrontasi ini merupakan tindakan keras pemerintah Indonesia terhadap Belanda yang bersih keras tidak mau menuntaskan kasus Papua. Sehingga tak ada jalan lain bagi Indonesia selain mengerahkan unsur kekuatan militernya. Pengerahan kekuatan militer ini mendekatkan Indonesia kepada Uni Sovyet untuk mendapatkan bantuan persenjataan. Disamping pembelian senjata pada negara-negara Barat yang tidak setujui oleh pihak Amerika Serikat dan sekutunya.

Langkah konfrontasi merupakan suatu sikap permusuhan atau menentang tindakan Belanda yang terus membelenggu Papua dengan kebijakan kolonialnya, sehingga membuat Indonesia mengerahkan seluruh unsur kekuatan nasionalnya untuk membebaskan Papua (Syarifuddin, 2017, h. 212).

Ketika Belanda mulai membuat kebijakan yang menjadikan Papua sebagai negara tersendiri yang terpisah dari NKRI. Hal ini membuat Indonesia melakukan reaksi keras untuk mengeluarkan maklumat Tri Komando Rakyat (Trikora) pada tahun 1961 sebagai kebijakan konfrontasi militer untuk membalas tindakan keras Belanda yang tetap tidak mau menyelesaikan kasus Papua.

Dengan diucapkannya Trikora, dimulailah konfrontasi terhadap Belanda. Kemudian pemerintah Indonesia membentuk Komando Mandala Pembebasan Papua dengan mengerahkan kekuatan militernya untuk 
membebaskan Papua yang sangat ditekankan dan dilaksanakan melalui beberapa operasi militer agar tercapai keberhasilan untuk merebut Papua dari kolonial Belanda (Syarifuddin, 2017, h. 443).

Pada mulanya Belanda mencemooh pembentukan Komando Mandala tersebut. Mereka mengira bahwa pasukan Indonesia tidak mungkin dapat masuk ke wilayah Papua. Ternyata operasi-operasi infiltrasi pasukan Indonesia berhasil merebut dan menduduki Kota Teminabuan. Hal tersebut memaksa Belanda bersedia untuk duduk di meja perundingan guna menyelesaikan sengketa Papua. Dunia luar termasuk Amerika Serikat yang semula mendukung posisi Belanda di forum PBB mulai menyadari bahwa Indonesia tidak main-main dengan tuntutannya (Poesponegoro, 2008, h. 441).

Karena Uni Sovyet memiliki teknologi militer yang tidak kalah dengan Barat, maka peralatan dan senjata yang diperoleh Indonesia cukup untuk membuat kekuatan militer terkuat di Asia Tenggara. Sehingga perkembangan itu menciptakan perubahan penting dalam perimbangan politik dan militer di Asia Tenggara. Belanda dan Amerika Serikat bukannya tidak tahu tentang perubahan itu. Jadi, pihak AS berkesimpulan harus mendesak Belanda untuk mengalah kepada kehendak Indonesia. Dengan pengerahan kekuatan militer yang telah diperlihatkan oleh Komando Mandala mengakhiri perlawanan Belanda yang tidak mau menyerahkan Irian Barat kepada Indonesia. Pada waktu itu kekuatan militer Indonesia sudah berada di berbagai tempat di Papua, sedangkan Belanda sudah mulai terdesak (Suryohadiprojo, 1996, h. 117-119). Saat itu pula, pihak Belanda mulai menyadari bahwa harga yang harus dibayar dalam mempertahankan kedaulatan Papua kemungkinan mahal dan mengakibatkan peperangan berlarut-larut yang tiada akhir.

Dengan pengerahan kekuatan militer melalui Tri Komando Rakyat (Trikora) ini akhirnya berhasil memaksa Belanda mau merundingkan kembali untuk menyelesaikan kasus Papua ini. 


\section{Diplomasi Tertutup}

Diplomasi tertutup diartikan ketika kedua negara secara paksa dipertemukan dalam upaya perdamaian dalam hal sengketa ataupun perselisihan dengan ikut campur tangan PBB melalui Sekretaris Jenderal PBB sebagai penengah.

Diplomasi tertutup terjadi dimana ada pertukaran pandangan secara tertutup oleh para wakil-wakil negara, melalui jabatan penting Sekretaris Jenderal PBB sebagai organisasi dunia, di luar dari kemilau publisitas. Sebab, lebih memajukan perkembangan diplomasi secara tertutup, Sekretaris Jenderal PBB memainkan peran yang menonjol. Sesungguhnya tipe diplomasi ini hanya bisa subur dalam lingkungan badan dunia seperti PBB dimana para wakil-wakil negara bisa berunding secara tertutup atau diam-diam tetapi tidak perlu secara rahasia, baik secara bilateral maupun multilateral diluar pandangan publik. Bagi negara-negara besar, tipe diplomasi ini yang paling efektif. Ketika mereka tidak bisa memperbaharui sikap-sikap secara terbuka, mereka tanpa kehilangan muka yang hampir tidak bisa dilakukan. Mereka bisa berunding secara tertutup, baik secara bilateral maupun melalui jasa baik PBB (Roy, 1995, h. 161).

Hasil nyata dalam upaya penyelesaian Papua baru terlihat tatkala tahun 1962, Sekjen PBB U Thant mengambil prakarsa agar masalah Papua dirundingkan antara Indonesia dan Belanda. Nota yang diajukan berdasarkan pokok-pokok diplomat Elsworth Bunker. Persetujuan tersebut menyatakan bahwa penyerahan wilayah Papua dilalui perantara Badan Sementara PBB yaitu UNTEA, yang kemudian akan diserahkan kepada Indonesia. Lalu persetujuan tersebut diterima kedua belah pihak dan setelah itu ditandatangani di Markas Besar PBB tanggal 15 Agustus 1962. Persetujuan tersebut dinamakan persetujuan New York (Wisnumurti, 1998, h. 79). 
Dengan ditandatangani persetujuan New York dengan pengawasan langsung dari PBB, tuntutan Indonesia untuk menyatukan wilayah Papua ke dalam kekuasaan pemerintahan Indonesia ternyata dapat dipenuhi oleh Belanda melalui suatu masa peralihan pemerintahan yang diselenggarakan oleh pihak ketiga, ialah Badan Pemerintahan Sementara PBB atau UNTEA (Syarifuddin, 2017, h. 449).

PBB mengambil alih pemerintahan di wilayah Papua sebelum menyerahkannya kepada Indonesia mulai dari 01 Oktober 1962 hingga 01 Mei 1963. Untuk mempersiapkan penyerahan wilayah tersebut kepada Indonesia, maka PBB melalui UNTEA telah mempersiapkan 1.500 personil yang tergabung dalam pasukan PBB di Irian Barat yaitu UN Security Force in West Irian-UNSF. Tugas UNSF ialah memantau gencatan senjata dan menjamin tertib hukum di wilayah tersebut yang mencakup sebagai penanggungjawab administratif atau penguasa sementara (Wisnumurti, 1998, h. 79).

Dalam menyelenggarakan pemerintahan di Irian Barat, UNTEA berkewajiban melaksanakan tugas-tugas antara lain memelihara keamanan dan ketertiban umum, serta mengumumkan dan menerangkan secara luas ketentuan-ketentuan dalam persetujuan Indonesia dan Belanda serta memberitahukan kepada penduduk Irian Barat mengenai penyerahan pemerintahan kepada pihak Indonesia dan mengenai ketentuan-ketentuan penentuan nasib sendiri sebagaimana ditetapkan dalam persetujuan (Ridhani, 2009, h. 230). Dengan demikian, maka mulai tanggal 01 Mei 1963 wilayah Irian Barat secara de facto maupun de jure masuk ke dalam wilayah kesatuan kekuasaan RI.

Keberhasilan penyelesaian sengketa antara Belanda dan Indonesia dalam menyelesaikan kasus Papua melalui persetujuan New York ini tak lepas dari langkah seorang Sekretaris Jenderal PBB, U Thant yang mengambil 
langkah perdamaian. Hal ini sesuai pendapat Sefriani (2016), menyatakan bahwa:

Sekjen PBB merupakan mediator atau memberikan jasa baik untuk pihak-pihak bersengketa. Hal ini dikarenakan pada umumnya seorang Sekjen PBB dianggap netral, dan memiliki kompetensi untuk membantu menyelesaikan sengketa oleh kedua belah pihak yang bersengketa. Dalam menjalan tugasnya, Sekjen PBB tidak boleh menerima perintah atau instruksi dari negara manapun (h. 366).

Melalui usul diplomat Ellsworth Bunker yang diperintah langsung oleh Sekjen PBB U Thant, usulan ini menjadi jalan keluar menuju perdamaian untuk menghentikan perselisihan antara Indonesia dan Belanda atas masalah Papua, sebagaimana kebijakan diplomasi yang dilakukan dengan cara tertutup.

Persetujuan New York merupakan strategi akhir diplomasi Indonesia yang dilakukan secara tertutup, akhirnya tercapailah suatu kesepakatan atas konflik Papua melalui perantara PBB. Pihak Belanda sepakat menyerahkan wilayah itu kepada UNTEA, sebagai pemerintahan sementara PBB di Papua yang selanjutnya akan diserahkan kepada pemerintah Indonesia. Dengan demikian, sesungguhnya keberhasilan pembebasan Papua merupakan keberhasilan diplomasi Indonesia yang disertai dengan strategi militer yang melibatkan kekuatan dunia Internasional, yaitu persaingan antara Blok Barat dan Blok Timur. Sebab, pendekatan kepada Uni Sovyet atas bantuan persenjataan militer, serta bantuan dukungan diplomasi yang diberikan Amerika Serikat telah mampu membantu penyelesaian konflik mengenai Papua ini.

\section{PENUTUP}

Berdasarkan hasil penelitian dan pembahasan, maka strategi diplomasi yang dilakukan Indonesia dalam pembebasan Papua tahun 19491962 dapat disimpulkan sebagai berikut: 
1. Strategi Diplomasi Terbuka, merupakan kebijakan diplomasi dengan cara terbuka yang dilakukan pemerintah Indonesia dalam menyelesaikan sengketa Papua. Diplomasi terbuka ini ditempuh melalui Sidang Majelis Umum Perserikatan Bangsa-Bangsa (1954-1957), dan dukungan dari negara-negara peserta Konferensi Asia Afrika (1955) di Bandung.

2. Kebijakan Konfrontasi Pasca Gagalnya Diplomasi, merupakan tindakan keras pemerintah Indonesia terhadap Belanda ketika upaya diplomasi yang dilakukan Indonesia dalam pembebasan Papua mengalami kegagalan. Konfrontasi ini membuat Indonesia menyerukan konsep Tri Komando Rakyat (Trikora) sebagai langkah pengerahan kekuatan militer dengan membentuk Komando Mandala Pembebasan Papua.

3. Strategi Diplomasi Tertutup, merupakan kebijakan diplomasi secara tertutup atas prakarsa dari Sekjen PBB untuk menyelesaikan masalah Papua tanpa adanya campur tangan dari negara lain. Prakarsa tersebut berdasarkan nota perdamaian dari diplomat Elsworth Bunker yang melahirkan Persetujuan New York sebagai penyelesaian sengketa Papua antara pemerintah Indonesia dengan Belanda.

\section{DAFTAR REFERENSI}

Abdurahman, D. (2007). Metodologi Penelitian Sejarah. Yogyakarta: Ar-Ruzz Media.

Cholil, M. (1979). Sejarah Operasi-operasi Pembebasan Irian Barat. Jakarta: Departemen Pertahanan Keamanan Pusat Sejarah ABRI.

Djaja, W. (2015). Sejarah Eropa: Dari Eropa Kuno Hingga Eropa Modern. Yogyakarta: Ombak.

Gottschalk, L. (1985). Mengerti Sejarah. Jakarta: Universitas Indonesia Press.

Irwanto, D. \& Syair, A. (2012). Metodologi Sejarah dan Historiografi. Palembang: Proyek SP4 Universitas Sriwijaya.

Karseno. (2011). Dinamika Politik Indonesia dalam Perjuangan Diplomasi Pembebasan Irian Barat, 1949-1963. Jurnal Sejarah Citra Lekha, XV (1). 
Poesponegoro, M.D. \& Notosusanto, N. (2008). Sejarah Nasional Indonesia VI: Zaman Jepang dan Zaman Republik. Jakarta: Balai Pustaka.

Ridhani, R. (2009). Mayor Jenderal Soeharto: Panglima Komando Mandala Pembebasan Irian Barat. Jakarta: Pustaka Sinar Harapan.

Rochmat, S. (2009). Ilmu Sejarah Dalam Perspektif Ilmu Sosial. Yogyakarta: Graha Ilmu.

Roy, S.L. (1995). Diplomasi. Jakarta: PT Rajagrafindo Persada.

Sefriani. (2016). Peran Hukum Internasional dalam Hubungan Internasional Kontemporer. Jakarta: Rajagrafindo Persada.

Setyawan, A.A \& Darlis, A.M. (2011). Resimen Pelopor: Pasukan Elit yang Terlupakan. Yogyakarta: Matapadi Presindo.

Suryohadiprojo, Sayidiman. (1996). Kepemimpinan ABRI dalam Sejarah dan Perjuangannya. Jakarta: Intermasa.

Syarifuddin. (2017). Buku Ajar Sejarah Nasional Indonesia VI. Jakarta: Pasca Sarjana UNJ Press.

Usman MHD, S. \& Din, I. (2010). Pasang Surut Sejarab Papua dalam Pangkuan Ibu Pertiwi. Jakarta: Planet Buku.

Wisnumurti, Nugroho. (1998). Politik Luar Negeri Indonesia Bagi Terciptanya Perdamaian dan Keamanan Dunia Melalui Perserikatan Bangsa-Bangsa. Jurnal Ketahanan Nasional, III (1) 